\title{
Regulatory Sanctions and Reputational Damage in Financial Markets
}

\author{
John Armour, Colin Mayer, and Andrea Polo*
}

\begin{abstract}
We study the impact of the enforcement of financial regulation by the United Kingdom's regulatory authorities on the market price of penalized firms. Existing studies rely on analyses of multiple events that may distort the measurement of reputational losses. In the United Kingdom, the entire enforcement process involves only one public announcement and is accompanied by complete information on legal penalties. We find that reputational losses are nearly nine times the size of fines and are associated with misconduct harming customers or investors but not third parties.
\end{abstract}

\section{Introduction}

Reputational losses can be an important deterrent to misconduct (Klein and Laffler (1981), Shapiro (1983)). A common procedure for estimating reputational loss is to measure the impact of the revelation of information about firm conduct on market values and associated costs. ${ }^{1}$ Using this procedure, researchers have found that reputational losses resulting from misconduct affecting a firm's customers, suppliers, or investors are large and significant, whereas losses associated with misconduct involving third parties (such as market participants in general or

*Armour, john.armour@law.ox.ac.uk, Faculty of Law, University of Oxford; Mayer, colin.mayer@sbs.ox.ac.uk, Saïd Business School, University of Oxford; and Polo (corresponding author), andrea.polo@upf.edu, Universitat Pompeu Fabra and Barcelona GSE. We are grateful to an anonymous referee and Jarrad Harford (the editor) for helpful comments on a previous version of this article. We gratefully acknowledge financial support from the Oxford University Centre for Corporate Reputation. We thank Cindy Alexander, Jennifer Arlen, Sara George, Ed Glaeser, Jeff Gordon, Jonathan Karpoff, Michael Knight, Meziane Lasfer, Jose Martinez, Alan Morrison, Richard Zeckhauser, and seminar and conference participants at the 2012 Annual Meeting of the American Finance Association in Chicago, the Bank for International Settlements, Bucerius Law School, the Financial Services Authority (in London and Wilton Park), Harvard University, Hebrew University of Jerusalem, Lancaster University, Oxford University, and Yale University.

${ }^{1}$ See Karpoff (2012) for an extensive survey. Specific examples include Jarrell and Peltzman (1985) on product recalls; Mitchell and Maloney (1989) on air safety disasters; Karpoff and Lott (1993) and Murphy, Shrieves, and Tibbs (2009) on frauds perpetrated on related parties; Karpoff, Lott, and Wehrly (2005) on environmental violations; Karpoff and Lott (1999) on punitive damage awards; and Karpoff, Lee, and Martin (2008) on financial misrepresentation. 
the public at large) are small and insignificant (Karpoff and Lott (1993), Murphy et al. (2009)). ${ }^{2}$

A significant problem with prior studies, mostly based on U.S. data, is that information about misconduct and associated penalties for offending firms is typically revealed over an extended period that "can stretch over several years" (Karpoff, Koester, Lee, and Martin (2014), p. 3). Often, the first announcement is that the regulator has commenced an investigation, and even this may be preceded by speculation in the press of a potential investigation. Later announcements relate to the evolving investigation, finishing with information about whether the defendant has been found guilty and the size of associated fines. Furthermore, consequent on the regulatory ruling, there may be subsequent private litigation by investors. One study (Karpoff et al. (2008)) addresses this by cumulating marketvalue impacts across all identifiable announcements. However, this is subject to the concern that information leakages and confounding news might make these noisy or inaccurate measures of losses.

In this article, we are able to address this concern by exploiting a unique feature of the U.K. financial regulatory system: The entire enforcement process involves only one public announcement, which includes information about associated legal penalties. During the period of this study, U.K. regulators made public announcements only on completion of the enforcement process. The Financial Services Authority (FSA) and the London Stock Exchange (LSE) investigated firms for possible violations of financial regulations and listing rules but only made their investigations public once misconduct had been established and a fine and/or order to pay compensation had been determined. ${ }^{3}$

Moreover, and again in contrast to the United States, the announcement of an FSA or LSE enforcement action was unlikely to trigger any private litigation. Securities litigation, for example, is practically nonexistent in the United Kingdom (Armour, Black, Cheffins, and Nolan (2009)) because of differences in substantive law and litigation funding rules (Davies (2007)). This is highly significant for our purposes because it gives a much more precise and complete picture of announcements of regulatory sanctions to the market. The immediate inclusion of information about the size of financial payments and the absence of class-action claims mean that no assumptions need be made about the accuracy of the market's estimates of future financial penalties. Although the possibility of leakage of information prior to regulatory announcements cannot be entirely excluded, the sample employed in this study is a significant advance over previous studies in its ability to address the potential mismeasurements that may have arisen from multiple announcements.

\footnotetext{
${ }^{2}$ A recent study using a large sample of corporate lawsuits (Haslem, Hutton, and Smith (2017)) records smaller reputational losses than those reported in the previous literature. The smaller losses in this study may reflect the inclusion of less egregious lawsuits that do not involve class actions or regulatory interventions.

${ }^{3}$ U.K. regulators' practices changed after our sample period such that preannouncement of investigations prior to their completion has now become commonplace. Consequently, the data reported in this study are in effect the entire population of observations for which such a clear identification of reputational losses is possible.
} 
We conduct an event study of the impact of announcements of regulatory sanctions on disciplined firms in the United Kingdom. We find that reputational sanctions are large: Stock price reactions are on average nine times larger than the financial penalties imposed by the FSA. We also report that reputational losses are confined to misconduct that directly affects "second parties" (those who trade with the firm, e.g., customers and investors). The announcement of a fine for wrongdoing that harms "third parties" who do not trade with the firm (e.g., other market participants or those harmed by money laundering) has no impact on stock prices. In cross-sectional regressions, we find that the reputational sanction is unrelated to the size of the financial penalties levied, is smaller for larger firms, and increases in intensity after the financial crisis of mid-2007. In robustness tests, we are able to rule out the possibility that reputational losses are explicable as profits foregone from the curtailment of the proscribed activity.

The results in this article are consistent with a majority of previous studies. The more precise identification of announcement dates in this study therefore supports and significantly reinforces inferences about reputational losses that have been drawn from previous ones.

The rest of this article is structured as follows: Section II outlines the institutional framework of enforcement in the United Kingdom and formulates the hypotheses of the article. In Section III, we describe our data and methodology. Section IV presents the results, and Section V reports the conclusions.

\section{Institutional Structure and Hypotheses}

\section{A. The FSA and Its Approach to Enforcement}

The FSA was the United Kingdom's integrated financial regulator, with responsibility for banking, insurance, and financial market supervision, until 2013. ${ }^{4}$ It was established in 1997 and took over as regulator for the full range of activities in Dec. 2001 under the Financial Services and Markets Act (FSMA) 2000.

The FSA's Handbook contained a wide range of rules for the conduct of business and prudential requirements for financial firms, as well as the U.K. Listing Rules applicable to publicly traded companies listed on the LSE's Main List (FSMA). These rules were drafted with the FSA's statutory objectives in mind: maintaining market confidence, providing consumer protection, promoting public awareness of the financial system, and reducing financial crime.

The FSA had very wide enforcement powers, including the ability to pursue civil and, in certain serious cases, criminal sanctions against wrongdoers. The FSA also had the power to issue a public censure, in addition to or instead of any formal penalty.

Where enforcement action was taken, this ordinarily began with an investigation (Blair, Walker, and Purves (2009)). If the results of the investigation suggested that misconduct had occurred, the FSA had to decide what action to take, if any, and send a "warning notice" to the firm in question. This notice set out the details of what the FSA proposed to do and its reasoning for the decision.

\footnotetext{
${ }^{4}$ On Apr. 1, 2013, the FSA was abolished, and its roles were split between the Prudential Regulation Authority (PRA), concerned with the safety and soundness of financial institutions, and the Financial Conduct Authority (FCA), concerned with the conduct of financial institutions.
} 
The firm then had an opportunity to respond to and address the issues raised by the FSA. If the regulator was unpersuaded by the response, it issued a "final notice" giving details of any penalty or order. Typically, the firm did not contest the matter but instead agreed to a settlement with the FSA in the hope of obtaining a more lenient penalty. However, a final notice was still made even in cases where the settlement procedure had been used. Consequently, problems of sample selection that would likely arise if settlements between regulator and firm could be reached in private are not relevant here.

The timing of the release of information by the FSA concerning its enforcement activity was very different from that employed by the U.S. Securities and Exchange Commission (SEC). The governing legislation provided that the FSA should not release information about ongoing investigations until they had been concluded and a final notice had been issued, and even then, the FSA was to release information only in such a way as was "fair" to the party being investigated (FSMA). Final notices consequently usually contained no more than a summary statement of the facts supporting the FSA's conclusions and the details of all the fines and payments of compensation ordered.

In contrast to the United States, securities litigation is practically unknown in the United Kingdom because the legal environment lacks key procedural mechanisms necessary to support class-action litigation (Armour et al. (2009)). Consequently, the announcement of an FSA enforcement action was unlikely to trigger any private litigation. The foregoing features mean that the FSA's announcement of a final notice was a unique event associated with each enforcement action, conveying information that would encompass 3 or 4 separate announcements in a typical SEC case: investigation, conclusion, penalty, and civil actions. ${ }^{5}$

\section{B. The LSE and Alternative Investment Market Rules}

Whereas the FSA was responsible for the setting and enforcement of the Listing Rules governing firms on the LSE's Main List, the LSE itself was responsible for setting and enforcing the rules of its Alternative Investment Market (AIM) (LSE (2010)). Similar to the FSA, the LSE had powers to levy fines, to delist, or simply to issue statements of public censure of firms found to be in breach of the rules. ${ }^{6}$ The publicity surrounding enforcement was similar to that for the FSA: No public announcement was made until an investigation was completed (LSE (2009)).

\section{Formulation of Hypotheses}

A popular perception is that the FSA and LSE's enforcement activities did not impose any meaningful sanction on wrongdoer firms. ${ }^{7}$ However, investors

\footnotetext{
${ }^{5}$ It is, however, possible that in the case of international firms also publicly traded in the United States, an announcement of enforcement by the U.K. FSA might trigger subsequent class actions in the United States. We check for this possibility in our data, as discussed later in the article.

${ }^{6}$ AIM Rules for Companies, Feb. 2010, Rule 42. In contrast to the FSA, whose powers were derived from statute, the LSE's powers in relation to AIM-listed firms derived from firms' listing agreements, under which firms undertook to submit to LSE enforcement and pay any fines levied against them. Prior to Apr. 2010, the LSE had used those powers in only 7 cases.

${ }^{7}$ See, for example, The Times, July 7, 2009: "The threat of fines from the FSA are seen as a footling expense, just another cost of doing business, no different from paying the quarterly phone bill. The
} 
may react to new information released by the regulatory authorities regarding the financial misconduct of a firm. We therefore hypothesize that there is a "reputational loss":

Hypothesis 1. Reputational Loss. The publication of final notices of enforcement activity is associated with abnormal losses to the firm's shareholders, which exceed the value of any financial payments the firm is required to make.

If a firm is revealed to have abused the confidence of its customers, suppliers, or investors (second parties), its reputation and the terms on which it can trade with these parties in the future are likely to be adversely affected. Conversely, if a firm has profited at the expense of persons who are not connected with it (third parties), its customers, suppliers, and investors are not directly affected, and the terms on which it trades with them would not be expected to change (Karpoff and Lott (1993), Alexander (1999)).

Hypothesis 2. Second-Party versus Third-Party Wrongs. Abnormal losses associated with the publication of financial notices should be significantly larger where the prohibited conduct imposes losses on customers and/or investors than where the injured parties do not trade with the firm.

We conjecture that the reputational loss is related to the information content of the regulatory announcement. In particular, we consider whether it is smaller i) for cases where the fines are smaller because these are associated with less egregious offenses $;{ }^{8}$ ii) for large firms on which more information is available in the market domain; and iii) after the financial crisis of 2007, following which the degree of regulatory activity increases and may therefore be less informative about any particular case.

Finally, we examine and seek to distinguish another possible explanation of a market sanction exceeding the value of any mandated payments, namely, that it is simply due to a loss of profits on the prohibited activity (Karpoff and Lott (1993)).

\section{Data and Methodology}

\section{A. FSA and LSE Enforcement Data}

We examine all the press statements related to enforcement actions by the FSA and the LSE on their Web sites ${ }^{9}$ over the period Jan. 2001-Jan. 2011. ${ }^{10}$ There are 341 cases. Shortly thereafter, the FSA and LSE relaxed the restriction that announcements about an investigation would only be made once it had been completed. This is therefore the population of investigations where the event date

embarrassment factor no longer counts for much, alas. There is not much shame in being on the receiving end of a fine" (July 7, 2009).

${ }^{8}$ According to the Decision Procedures and Penalties Manual of the FSA (2010), one of the principles of determining the level of penalties was that they should reflect the seriousness of the breach.

${ }^{9}$ http://www.fsa.gov.uk/pages/library/communication/notices/index.shtml and http://www.london stockexchange.com/companies-and-advisors/aim/advisers/aim-notices/aim-notices.htm

${ }^{10} \mathrm{We}$ hand-collect the data. This allows us to avoid the potential biases, over-restrictiveness, or over-inclusion that could afflict financial misconduct research in the United States, which relies on public databases for its analysis, as discussed by Karpoff et al. (2014). 
was precisely and uniquely specified. Because we are interested in the share price reaction following the press statements, we construct a database of all the press statements announcing sanctions imposed on listed companies or subsidiaries of listed companies. We drop all cases relating to individuals or nonlisted companies. After this first filter has been applied, we obtain a sample of 83 cases.

We take pains to exclude cases in which information about the specific case or the investigation leaked into the market before the regulator's press statement. To identify these, for each of the 83 cases, we check Factiva to see whether there are any press reports about the specific cases in the 2 years before the event. We complement the analysis of Factiva data with a search on the LexisNexis database looking at the news in the categories "Law and Legal System" and "Crime, Law Enforcement \& Corrections" in the 2 years before the announcement and up to 2 years following the announcement to confirm that there is no additional public or private enforcement activity on the case. In most cases, we find nothing. However, we find announcements in three types of cases: i) where there is media speculation about an investigation at a particular company; ii) where there is "voluntary" disclosure by the company that it is under investigation; iii) where the FSA decides to make an investigation public, for instance, because it is thought that this would bring forward witnesses (FSA (2010)); and iv) where an enforcement action on the same case starts in another country. In total, we find 28 such cases where the information is in the public domain before the regulator's press statement. We drop these from the main analysis. ${ }^{11}$

Because an advantage of this study is that the size of the penalty is precisely identified on the day of the initial announcement, we filter out 7 cases where the press statement by the FSA or the LSE simply states that "customers will be compensated as appropriate" without specifying the actual amount of the compensation. Any share price decrease in such cases could be a consequence of uncertainty about the amount of compensation to be offered by the company. In these cases, announcements are not fully informative and are therefore excluded from the analysis.

Moreover, we exclude 3 cases for which there has been a change of ownership in the investigation period and 5 further cases for which other potentially confounding news about the company (unrelated to the regulatory notice) is announced in the newspapers the day before, the day of, or the day after the press announcement about the misconduct.

Having conducted these filtering exercises, we obtain a clean data set of 40 events for which the regulatory announcement is unique and contains the full details of any financial payments by way of fine or compensation that the firm is required to pay as a consequence. Of these, 37 are enforcement actions by the FSA, and 3 are actions by the LSE. For the FSA, enforcement activity covers the full range of financial services regulation and the U.K. Listing Rules. For the LSE, it covers only breaches of the AIM Rules. The average market capitalization of the sanctioned firms in our sample is more than $£ 23$ billion, but the dispersion is very

\footnotetext{
${ }^{11}$ Although we have undertaken a press search that is as extensive as possible, the absence of references to investigations does not rule out the possibility of leakage of information by rumors and word of mouth.
} 
high. The average financial payment is $0.26 \%$ of market capitalization. In total, 29 firms in the sample are financial companies, and 17 of the 40 cases occur after the start of the subprime crisis, which we take to have occurred in June 2007. A brief description of each case is reported in the Appendix, and descriptive statistics are reported in Table 1 .

\section{TABLE 1}

\section{Descriptive Statistics}

Table 1 reports the number of cases of financial misconduct sanctioned by the Financial Services Authority (FSA) and the London Stock Exchange (LSE) involving customers and investors in Panel A and third parties in Panel B together with the nature of the wrongdoings. Panel $\mathrm{C}$ reports some descriptive statistics of the sample. We report the average, the median, the maximum and minimum values of market capitalization, and the financial penalty expressed as a percentage of market capitalization. We also report the number of cases happening after (versus before) June 2007, sanctioned by the FSA (versus the LSE), and relating to financial (versus nonfinancial) companies. The sample consists of the 40 cases obtained after applying the filters described in Section III.

Panel A. Wrongs against Customers or Investors

Mis-Selling of
Products

Products

Misleading

Advertisements

2

\section{Timing of Announcements to the Market}

6

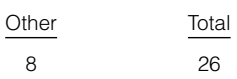

Panel B. Wrongs against Third Parties

Compliance with Money Laundering Rules 4

Market Misconduct 2

Panel C. Descriptive Statistics

$\frac{\text { Variable }}{\text { MARKET_SIZE (Emillions) }}$

FINANCIAL_PAYMENT:

FINE + COMPENSATION

(\% of market size)

POST_CRISIS

FSA

FINANCIAL_COMPANIES

\section{$\underline{\text { Maximum }}$}

$108,004.50$

2.51
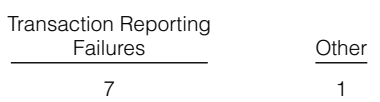

$\frac{\text { Total }}{14}$

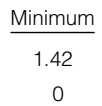

0 $\frac{\text { Median }}{19,109.15}$

0.01 $\frac{\text { Mean }}{23,615.59}$

0.26

\section{B. Characterization of Wrongs}

To test Hypothesis 2, we subdivide the sample according to whether the sanctioned misconduct is committed against customers and/or investors (26 cases) or against a third party (14 cases). This classification is performed on a functional, rather than a legal, basis. In the first category, we include mis-selling of financial products and misleading advertisements, both of which harm customers, and tardy announcements of information to the market where mandated, which we take to harm the firm's investors. We refer to this category as "second-party" wrongs because the harm in each case is done to persons who are in an existing contractual relation with the firm.

In the second category, we include failure to comply with "gatekeeper" obligations designed to minimize the risk of money laundering by a firm's clients, market misconduct (e.g., trading in stocks to move the market price), and failures to comply with obligations to report transactions in other firms' securities. The harm resulting from these failings is borne by persons other than the firm's own customers or investors. We refer to this category as "third-party" wrongs. 


\section{Event-Study Methodology}

We employ standard event-study methodology (Fama, Fisher, Jensen, and Roll (1969)) to evaluate the stock price reaction to the public announcement of misconduct. We calculate the abnormal share price reaction around the event. We use the market model as a benchmark of normal returns. ${ }^{12}$ The abnormal return (AR) for firm $i$ at day $t$ is defined as

$$
\mathrm{AR}_{i, t}=\mathrm{R}_{i, t}-\alpha_{i, t}-\beta_{i} \mathrm{R}_{m, t}
$$

where $\mathrm{R}_{i, t}$ and $\mathrm{R}_{m, t}$ are the returns on firm $i$ 's common stock on day $t$ and the index of market returns on day $t$, respectively. The coefficients $\alpha_{i}$ and $\beta_{i}$ are estimated from an ordinary least squares (OLS) regression of $\mathrm{R}_{i, t}$ on $\mathrm{R}_{m, t}$ using a 260-day period consisting of days -261 to -2 relative to the announcement day. The average abnormal return for each day $t$ in the event window is computed as

$$
\mathrm{AR}_{t}=\frac{\sum_{i=1}^{N} \mathrm{AR}_{i, t}}{N},
$$

where $N$ is the number of firms over which abnormal returns are averaged on day $t$. The cumulative average abnormal return for the window $t_{1}, t_{2}$ is defined as

$$
\operatorname{CAR}\left(t_{1}, t_{2}\right)=\sum_{t=t_{1}}^{t_{2}} \mathrm{AR}_{t} .
$$

Parametric $t$-statistics for the mean abnormal returns are calculated from the cross-sectional standard error of abnormal returns. To make sure that the presence of outliers does not bias our results, we winsorize the abnormal returns before estimating the test statistic. We set all outliers to a 90th percentile of the data, meaning that all data below the 5th percentile are set to the 5th percentile, and data above the 95th percentile are set to the 95th percentile.

\section{Results}

\section{A. Effect on Market Valuation}

Table 2 shows the average cumulative abnormal returns (CARs) in the event windows $(0),(0,1),(-1,1)$ and the associated $t$-statistics and nonparametric $z$-statistics. We find that press statements by the FSA and the LSE about corporate misconduct result in statistically significant losses in shareholder wealth. These results are robust to i) using the non-winsorized variables, ii) dropping the outlier instead of winsorizing, and iii) using a different benchmark model of normal returns (market model with $\alpha=0$ and $\beta=1$ ). We focus our attention on the

\footnotetext{
${ }^{12}$ On this, we follow Bhagat and Romano ((2002), p. 146): "Since several studies have found evidence inconsistent with the economic models, in particular CAPM, the use of such restrictions is not appropriate. Hence most researchers have begun to rely on the statistical models to estimate the expected returns." In any event, in short-horizon event studies, the test statistic specification is not highly sensitive to the benchmark model of normal returns (Kothari and Warner (2007)).
} 


\section{CARs around the Press Statement of Misconduct}

\begin{tabular}{|c|c|c|c|c|c|}
\hline Sample & $\begin{array}{l}\text { Announcement } \\
\text { Window } \\
\end{array}$ & $\begin{array}{l}\text { MARKET- } \\
\text { REACTION } \\
\end{array}$ & $t$-Stat. & $z$-Stat. & $\begin{array}{l}\text { No. of } \\
\text { Obs. }\end{array}$ \\
\hline All & $\begin{array}{c}(0) \\
(0,1) \\
(-1,1)\end{array}$ & $\begin{array}{l}-1.26 \\
-1.16 \\
-1.68\end{array}$ & $\begin{array}{l}-2.55^{\star \star \star} \\
-1.66^{\star \star} \\
-1.97^{\star \star}\end{array}$ & $\begin{array}{l}-1.96^{\star \star} \\
-2.80^{\star \star \star} \\
-2.94^{\star \star \star}\end{array}$ & $\begin{array}{l}40 \\
40 \\
40\end{array}$ \\
\hline $\begin{array}{l}\text { CUSTOMERS_INVESTORS } \\
\text { THIRD_PARTY }\end{array}$ & $\begin{array}{l}(-1,1) \\
(-1,1)\end{array}$ & $\begin{array}{r}-2.62 \\
0.24 \\
\end{array}$ & $\begin{array}{l}-2.21^{\star \star \star} \\
0.22\end{array}$ & $\begin{array}{l}-3.54^{\star \star *} \\
0.91\end{array}$ & $\begin{array}{l}26 \\
14 \\
\end{array}$ \\
\hline
\end{tabular}

event window $(-1,1)$ to capture the full impact of the event on the share price and to account for potential leakage of information the day before the press statement by the regulators. The 3-day average cumulative abnormal return is $-1.68 \%$ and statistically significant (the $t$-statistic is -1.97 , and the Wilcoxon signed-rank $z$-statistic is -2.94). This result is robust to i) excluding the 3 LSE cases and ii) also excluding 5 cases for which it may be argued that they were not totally unexpected. ${ }^{13}$ This shows that the U.K. enforcement actions are not trivial.

The reported abnormal share price reaction of $-1.68 \%$ is an average of the effect of all press statements in our sample. By decomposing the sample into cases involving second- and third-party wrongs, we can distinguish results where investors and customers have been affected from those relating to third parties, such as the state or other companies' investors. The bottom of Table 2 reports the CARs in the event window $(-1,1)$ for these two categories. We observe that shareholder wealth effects are highly dependent on this stratification. Whereas second-party wrongs (against customers and investors) are associated with a $-2.62 \%$ share price reaction that is strongly statistically significant (the $t$-statistic is -2.21 , and the Wilcoxon signed-rank $z$-statistic is -3.54), third-party wrongs are in fact characterized by a positive stock price reaction of $0.24 \%$, although this is not statistically significant. ${ }^{14}$ The difference in market reactions among the two groups is statistically significant using both parametric and nonparametric tests.

In Figure 1, we enlarge the event window to -10 days, +10 days and plot the CARs for the 2 subgroups. From this picture, we can confirm that there is no evidence of leakage of information before day -1 and that the negative share price

\footnotetext{
${ }^{13}$ The 5 excluded cases are as follows: 3 cases for which we find evidence of media speculating before the announcement that a company, together with the rest of the companies in the same industry, may be characterized by a common malpractice; 1 case where JP Morgan is sanctioned 1 year before in the United States for a similar wrongdoing but in a completely different case; and 1 case in the thirdparty subgroup where the Royal Bank of Scotland (RBS), together with 19 other banks, is named by the U.K. High Court as having handled money of the Nigerian dictator, and 1 year later, the RBS receives a fine for money laundering in a different case.

${ }^{14}$ Insofar as share price reactions represent an updating of investors' priors about the likelihood of misconduct and the form that it takes, the positive but insignificant share price reaction to revelation of third-party cases may reflect a positive reaction to the news that a second-party violation is not uncovered rather than a positive perceived benefit of a third-party violation.
} 


\section{FIGURE 1}

\section{CARs $(-10,10)$ for the Two Types of Wrongdoings}

Figure 1 shows cumulative abnormal returns (CARs) over the 21 days, from -10 to +10 , around the announcement of misconduct. We split the sample between wrongdoings against customers or investors and third parties. The sample consists of the 40 cases obtained after applying the filters described in Section III.A. Cumulative abnormal returns are based on market model parameters calculated over the period -261 days to -2 days relative to the announcement date. Three cases (numbers 27, 30, and 31 in the Appendix) have been excluded because of substantial confounding announcements over the same period.

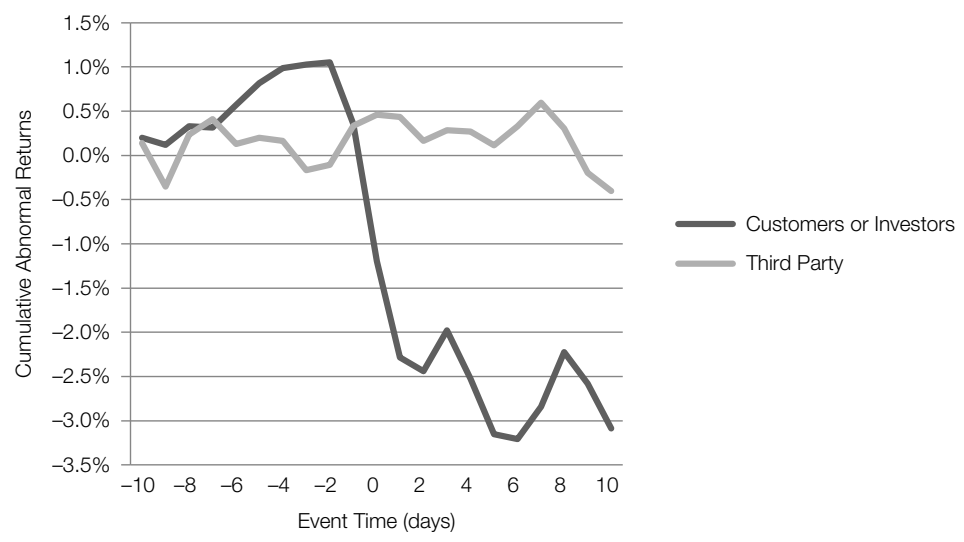

reaction for the customers or investors subgroup is not reversed in the subsequent 10 days.

As a test of the filtering exercise, in Table 3 we report the results of 3 larger samples $(51,63$, and 80$)$ obtained by progressively reintroducing the cases that we filtered out according to their degree of reliability. In Panel A of Table 3, we reintroduce 11 cases of leakage of information (but not where there is also a confounding event or a parallel enforcement case in the United States), summing the share price reactions during the announcement date and the first day in which the market became aware either of the misconduct or the investigation. In Panel B, we reintroduce a further 12 cases where there is no leakage, but there is some confounding information during the actual date (i.e., the compensation is not determined). In the last sample in Panel C, we also reintroduce cases where there is both leakage (summing the two events) and some confounding information. The results in Table 3 confirm the general pattern.

At this point, we do not know whether these market-valuation effects are due to reputational losses or to differences in the financial payments required of the defendant firms. The next section explores this question to test Hypotheses 1 and 2.

\section{B. Measuring Reputational Loss}

To measure reputational losses, we follow the "residual approach" used by, among others, Jarrell and Peltzman (1985), Karpoff and Lott (1993), and Karpoff et al. (2008). We calculate the change in the share price $\Delta V_{t}=V_{t}-V_{t-1}$ in the event window around the announcement of misconduct by the regulator and then subtract the amount of financial payments (fines and/or compensation) imposed 
TABLE 3

\section{CARs for Extended Samples}

Table 3 reports the cumulative abnormal returns (CARs) around the announcement of misconduct for 3 larger samples $(51,63$, and 80$)$ obtained by progressively reintroducing cases (according to their degree of reliability) to the sample of 40 cases used in the main analysis. We split the sample between wrongdoings against CUSTOMERS_INVESTORS and THIRD PARTY. In Panel A, we reintroduce 11 cases of leakage of information (but not where there is also a confounding event or a parallel enforcement case in the United States) summing the share price reactions during the announcement date and the first day in which the market becomes aware either of the misconduct or the investigation. In Panel B, we reintroduce 12 further cases where there is no leakage but there is some confounding information during the actual date (e.g., the compensation is not determined). In the last sample, in Panel C, we also reintroduce cases where there is both leakage (so we need to sum up two events) and some confounding information. CARs are based on market model parameters calculated over the period -261 days to -2 days relative to the announcement date. Abnormal returns are winsorized at $90 \%$. $t$-statistics are calculated from the cross-sectional standard error of abnormal returns. We also report the Wilcoxon signed-rank $z$-statistics. ${ }^{*},{ }^{* *}$, and ${ }^{* \star *}$ indicate significance at the $10 \%, 5 \%$, and $1 \%$ levels, respectively.

\begin{tabular}{|c|c|c|c|}
\hline Variable & Total & $\begin{array}{l}\text { CUSTOMERS_ } \\
\text { INVESTORS }\end{array}$ & $\begin{array}{l}\text { THIRD_ } \\
\text { PARTY }\end{array}$ \\
\hline \multicolumn{4}{|c|}{ Panel A. CARs $(-1,1)$ Separating the 2 Groups of Wrongdoings (51 cases) } \\
\hline $\begin{array}{l}\text { MARKET_REACTION } \\
t \text {-statistic } \\
z \text {-statistic } \\
\text { No. of obs. }\end{array}$ & $\begin{array}{l}-1.61 \\
-2.47^{\star \star \star} \\
-3.64^{\star \star \star} \\
51\end{array}$ & $\begin{array}{l}-2.25 \\
-2.77^{\star \star *} \\
-4.08^{\star \star \star} \\
35\end{array}$ & $\begin{array}{c}-0.001 \\
-0.6 \\
0.67 \\
16\end{array}$ \\
\hline \multicolumn{4}{|c|}{ Panel B. CARs $(-1,1)$ Separating the 2 Groups of Wrongdoings (63 cases) } \\
\hline $\begin{array}{l}\text { MARKET_REACTION } \\
t \text {-statistic } \\
z \text {-statistic } \\
\text { No. of obs. }\end{array}$ & $\begin{array}{l}-1.49 \\
-1.37^{\star} \\
-3.31^{\star \star \star} \\
63\end{array}$ & $\begin{array}{l}-2.09 \\
-1.47^{\star} \\
-3.90^{\star \star \star} \\
45\end{array}$ & $\begin{array}{r}0.14 \\
0.12 \\
1.06 \\
18\end{array}$ \\
\hline \multicolumn{4}{|c|}{ Panel C. CARs $(-1,1)$ Separating the 2 Groups of Wrongdoings ( 80 cases) } \\
\hline $\begin{array}{l}\text { MARKET_REACTION } \\
t \text {-statistic } \\
z \text {-statistic } \\
\text { No. of obs. }\end{array}$ & $\begin{array}{l}-0.92 \\
-1.17 \\
-2.79^{\star \star \star} \\
\quad 80\end{array}$ & $\begin{array}{l}-1.32 \\
-1.29 \\
-3.27^{\star \star \star} \\
57\end{array}$ & $\begin{array}{r}0.12 \\
0.14 \\
0.91 \\
23\end{array}$ \\
\hline
\end{tabular}

by the regulator: ${ }^{15}$

$$
\text { REPUTATIONAL_LOSS }=\Delta V_{t}-\text { FINE-COMPENSATION. }
$$

For each statement, we calculate the mandated financial payments (fines and compensation) as a percentage of the firm's value prior to the announcement event. Table 4 reports that the average fine for the entire sample is $0.15 \%$ of firm value. If we decompose the sample into the two types of wrong with which we are concerned, we observe that the average fine tends to be higher for wrongs against third parties $(0.19 \%)$ than for wrongs against customers and/or investors $(0.13 \%)$. The amount of compensation is 0 for the former group and $0.18 \%$ for the latter. The overall average compensation amounts to $0.12 \%$ of firm value. It is therefore clear that differences in financial payments do not explain the differences in market reaction between the two groups of wrongs.

In the bottom of Table 4, we subtract the total financial payment from the market reaction to measure the reputational loss as the residual. ${ }^{16}$ We observe

\footnotetext{
${ }^{15}$ In some cases, the press statements report two figures: the compensation to be paid and the compensation that has already been paid. We sum these figures because this is the first time that the misconduct and the associated amount of compensation have been announced to the market.

${ }^{16}$ Karpoff et al. (2008) also subtract the loss in share value that comes from investors revising the financial information on which they were previously valuing companies. This is not relevant to this study because even in those cases where sanctions relate to delayed timings of announcements to the market, regulatory sanctions come several months later, well after the announcement has been capitalized in market prices. This is a further advantage of the data used in this study.
} 
TABLE 4

Fine, Compensation, and the Reputational Loss

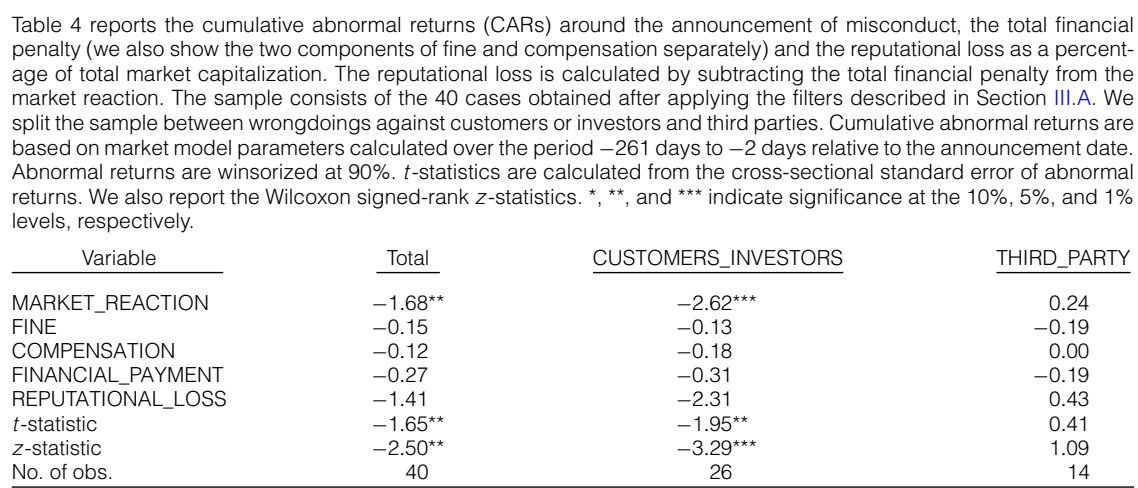

that reputational losses are negative and statistically significant for the entire sample $(-1.41 \%)$. This allows us to reject the null hypothesis in relation to Hypothesis 1, namely, that there is no reputational sanction associated with regulators' announcements.

Decomposing the sample, we see that the differences in overall market reaction are driven by differences in reputational losses rather than financial payments. The reputational loss for the customers or investors subgroup (i.e., second-party wrongs) is $-2.31 \%$ of market value and is strongly statistically significant. This result is robust to excluding the 3 LSE cases and also excluding the 5 cases discussed in footnote 13. For wrongs to third parties, the reputational effect is in fact positive $(0.43 \%)$, although it is not statistically significant. These results are consistent with Hypothesis 2, namely, that reputational losses are only incurred where harm is done to parties who trade with the firm.

\section{Cross-Sectional Differences in Reputational Losses}

In this section, we employ a cross-sectional multivariate regression analysis to examine the determinants of the reputational losses. The dependent variable is the reputational loss as defined in equation (4). We run OLS regressions with robust standard errors. We then multiply both sides of the equation by -1 to make the interpretation of regression results more intuitive; that is, a higher reputational loss is associated with a higher coefficient. Table 5 reports the results. In the first model, we simply use a dummy variable CUSTOMERS_INVESTORS as the regressor, which equals 1 when the wrongdoing is against customers or investors, and 0 otherwise. The positive and statistically significant coefficient is consistent with our earlier results.

In the second model, we introduce additional independent variables to test further hypotheses about the cross-sectional determinants of reputational sanctions. We include FINANCIAL_PAYMENT, which is the amount of the fine plus compensation as a percentage of firm value, as an independent variable in the regression; MARKET_SIZE, defined as the natural log of market value of common equity before the press statement; a dummy POST_CRISIS, which equals 


\begin{tabular}{|c|c|c|}
\hline \multirow[b]{2}{*}{ Variable } & \multicolumn{2}{|c|}{ REPUTATIONAL_LOSS } \\
\hline & 1 & 2 \\
\hline CUSTOMERS_INVESTORS & 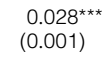 & $\begin{array}{l}0.015^{\star *} \\
(0.034)\end{array}$ \\
\hline FINANCIAL_PAYMENT & & $\begin{array}{c}-0.96 \\
(0.240)\end{array}$ \\
\hline MARKET_SIZE & & $\begin{array}{r}-0.004^{*} \\
(0.075)\end{array}$ \\
\hline POST_CRISIS & & $\begin{array}{l}0.021^{\text {*** }} \\
(0.009)\end{array}$ \\
\hline Industry fixed effects (financial versus nonfinancial) & No & Yes \\
\hline Intercept & $\begin{array}{c}-0.004 \\
(0.363)\end{array}$ & $\begin{array}{r}0.083^{*} \\
(0.060)\end{array}$ \\
\hline $\begin{array}{l}\text { No. of obs. } \\
R^{2}\end{array}$ & $\begin{array}{r}40 \\
0.20\end{array}$ & $\begin{array}{r}40 \\
0.56\end{array}$ \\
\hline $\begin{array}{l}F \\
\text { Prob. }>F\end{array}$ & $\begin{array}{l}13.52 \\
(0.001)\end{array}$ & $\begin{array}{l}12.80 \\
(0.000)\end{array}$ \\
\hline
\end{tabular}

1 if the date of the press statement is after June 2007, and 0 otherwise. Finally, we control for possible differences in the reaction of investors in financial and nonfinancial firms through a dummy variable that equals 1 for financial firms, and 0 otherwise. Having added these additional regressors, the coefficient of CUSTOMERS_INVESTORS is smaller but still highly statistically significant.

The variable FINANCIAL_PAYMENT is not statistically significant, implying that the size of the penalty does not serve as a signal of the seriousness of the reputational consequence of a wrong. ${ }^{17}$ Reputational sanctions are negatively and statistically significantly associated with MARKET_SIZE: The bigger the company, the smaller is the reputational sanction as a proportion of size. This is consistent with the prediction that there is more information in the market about larger firms, and consequently, the informational value to the market of

\footnotetext{
${ }^{17}$ The inclusion of FINANCIAL_PAYMENT as a regressor raises an issue of possible endogeneity if the FSA and LSE take into consideration the potential market impact of the penalties they levy. There is no suggestion that this is the case; the FSA's regulatory handbooks make no reference to reputational concerns in relation to determining the size of fines. According to the handbooks, the penalty is set in relation to i) the financial benefit to the wrongdoer, ii) the seriousness of the misconduct, iii) deterrence effects, and iv) mitigating factors (e.g., the degree of cooperation of the firm in question) (FSA (2009)). Nevertheless, to test for possible endogeneity, we undertake a 2-stage regression, using a variable that distinguishes between abuses that are "clearly profit enhancing" and those that are not (see footnote 18). Given the objectives of the FSA (in particular, item (i) on the list), this variable should be correlated with the financial penalty but not with reputational losses that reflect future worsening of terms of trade, and it should therefore satisfy the conditions of being an appropriate instrument. We find evidence that the variable is correlated with the financial penalty in the first-stage regression; however, the predicted value of the financial penalty is never significant in the second stage, suggesting that the absence of a correlation between the financial penalty and reputational losses is robust to corrections for possible endogeneity.
} 
an announcement by the regulator is proportionately smaller. Finally, we observe that the coefficient for POST_CRISIS is positive and statistically significant, implying that in the post-financial crisis world, reputational sanctions are more, not less, significant.

Very similar results are obtained when Tobit regressions are run instead of OLS, where the dependent variable is set to 0 when reputational sanctions are positive to avoid treating these cases as reputation-enhancing events. The results, both in the OLS and in the Tobit regressions, are robust if we winsorize the variable FINANCIAL_PAYMENT apart from the variable MARKET_SIZE, which becomes insignificant. If we bootstrap the standard errors, we obtain very similar results. If we drop the outlier instead of winsorizing, we obtain the same results except for the variable MARKET_SIZE, which is not significant in all the specifications. The postcrisis effect is closely associated with the 3 cases of the AIM-listed firms.

\section{Reputational Loss or Profits Foregone?}

We have interpreted the "residual" share price reaction (over and above mandated financial payments) as reputational loss, defined as the present value of the more expensive terms of trade in the future. However, it may be that some or all of these residual losses may be explicable as profits that will be foregone from loss of future earnings on the proscribed activity in question.

The striking differences in the market response to the 2 categories of misconduct are strongly suggestive that these losses are the result of reputational losses, not foregone profits. There is no reason to believe that foregone profits should vary so greatly depending on whether the harm is done against second or third parties. However, we perform an additional robustness check by distinguishing between cases involving activities that are "clearly profit enhancing" in impacting the cash flow of companies (e.g., mis-selling of products or misleading advertisements) from those that are not. ${ }^{18}$ If some or all of the market loss is due to profits foregone from ceasing to engage in the misconduct, we should observe larger market reactions (net of financial payment) in the first group.

To test this, we run a regression similar to that in Section IV.C on the subsample of cases of misconduct against customers or investors (25 cases), introducing the dummy variable CLEARLY_PROFIT_ENHANCING. We retain the control variables that had explanatory power in the prior specifications. The results reported in Table 6 show that this newly created dummy variable does not significantly enter the regression in the two specifications. The coefficient of the variable CLEARLY_PROFIT_ENHANCING is also not significant in the specifications where we drop the outlier instead of winsorizing, where we bootstrap the standard errors, or where we winsorize the variable financial penalty.

Therefore, the results do not appear to be driven by profits foregone from prohibited activities and further support our interpretation of these market losses as reputational sanctions.

\footnotetext{
${ }^{18}$ Examples of activities that are not clearly profit enhancing include failure to have effective systems and controls in place to protect consumers' confidential information, not carrying out customer orders on a timely basis, and failure to keep the market informed of price-sensitive information in a timely manner.
} 
Do Reputational Losses Reflect Foregone Profits?

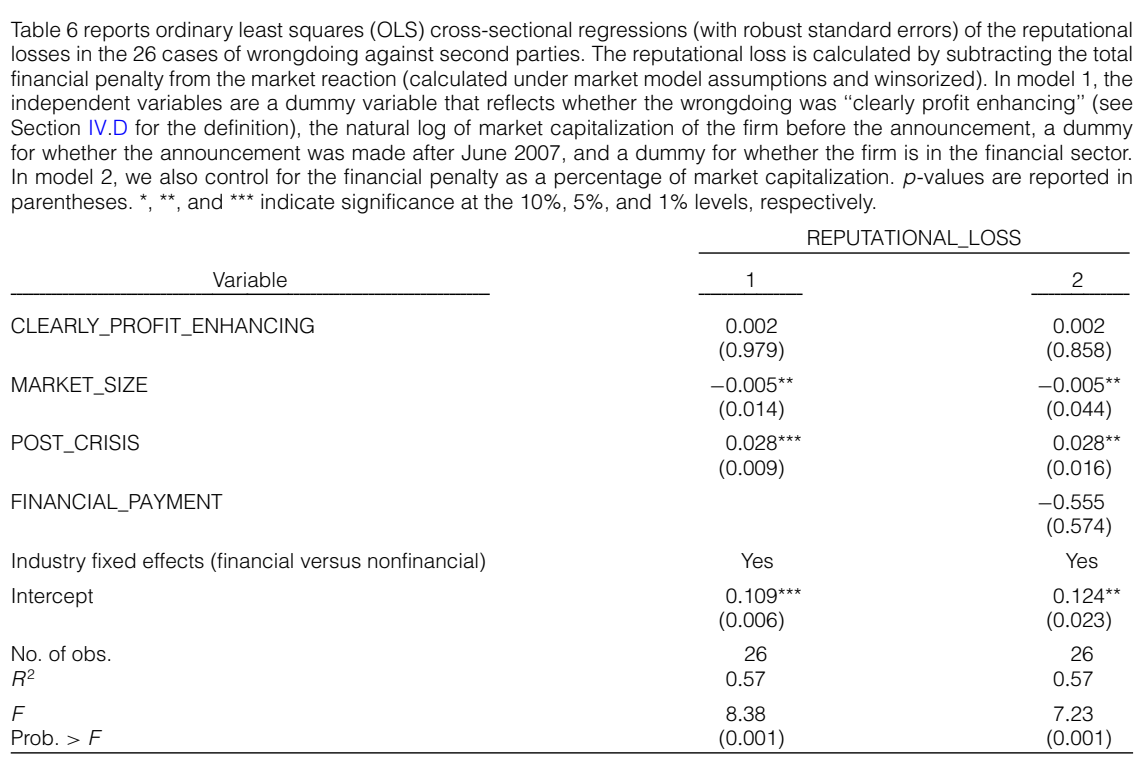

\section{Conclusions}

This article exploits a unique feature of the U.K. financial regulatory system over the period of this study: The entire enforcement process involves only one public announcement and is accompanied by complete information about legal penalties. This avoids potential errors that may have been introduced into previous analyses by multiple announcements over extended periods of time.

The article examines the impact on the market value of firms of enforcement by U.K. regulatory authorities for financial misconduct over the period 20012011. It records that penalized firms' stock prices experience statistically significant abnormal losses of approximately nine times the fines and compensation paid. We interpret the fall in equity market value in excess of mandated payments as the firms' reputational loss. Consistent with a majority of the prior literature (Karpoff (2012)), we find that reputational losses are confined to cases where the wrongdoing is against related parties (customers or investors). The more precise identification of the dates of enforcement in this article yields results that are consistent with most existing studies, therefore lending significant support to inferences that have been drawn from them about the impact of regulatory sanctions on reputational losses.

\section{Appendix. Description of Cases}

Table A1 reports a description of the cases obtained after applying the filters described in Section III.A. We obtain the information from press statements announcing the sanctions. 


\section{Description of the 40 Cases}

Table A1 reports a description of each of the 40 cases. For each case, we report the following information: i) the date of the press statement; ii) the name of the sanctioned company (when a nonlisted subsidiary is sanctioned, we report the names of both the subsidiary and the listed holding company); iii) the fine and the total compensation in U.K. pounds (where press statements report two figures, the compensation to be paid and the compensation that has already been paid, we sum both figures); iv) a brief description of the misconduct; v) our classification of the misconduct into a second- or third-party wrong; and vi) the regulatory authority.

\begin{tabular}{|c|c|c|}
\hline \# & Date & $\begin{array}{l}\text { Listed Holding } \\
\text { Company Name }\end{array}$ \\
\hline 1 & Sept. 25, 2001 & Credit Suisse \\
\hline 2 & Sept. 10, 2001 & AMP \\
\hline 3 & Dec. 17, 2002 & $\begin{array}{l}\text { Royal Bank of } \\
\text { Scotland }\end{array}$ \\
\hline 4 & Dec. 4, 2002 & Lloyds \\
\hline 5 & Dec. 10, 2003 & $\begin{array}{l}\text { Abbey National } \\
\text { companies }\end{array}$ \\
\hline 6 & Aug. 7, 2003 & $\begin{array}{l}\text { National Australian } \\
\text { Bank }\end{array}$ \\
\hline 7 & Mar. 27, 2003 & $\begin{array}{l}\text { Royal and Sun } \\
\text { Alliance Group }\end{array}$ \\
\hline 8 & Mar. 6, 2003 & Prudential \\
\hline 9 & Feb. 13, 2003 & HBOS \\
\hline 10 & Dec. 22, 2004 & $\begin{array}{l}\text { Bradford \& Bingley } \\
\text { Plc }\end{array}$ \\
\hline
\end{tabular}

\begin{tabular}{l}
\multicolumn{1}{c}{$\begin{array}{c}\text { Subsidiary } \\
\text { Name }\end{array}$} \\
\hline Winterthur Life \\
Pearl Companies \\
\\
Abbey Life \\
Assurance \\
Company Ltd.
\end{tabular}

Fine

500,000

100,000

750,000

$1,000,000$

$2,320,000$

Northern Bank

$1,250,000$

950,000

Scottish Amicable

Bank of Scotland

750,000

750,000

650,000
Total

Compensation

$10,000,000$

345,854

0

$140,000,000$

300,000

0

$16,600,000$

$11,000,000$

10,350

$6,000,000$

Second
Party
(S) or

(S) or $\quad$ Third $\quad$ FSA

Party
$(\mathrm{T})$

$\frac{\text { Nature of Misconduct }}{\text { Mis-selling of mortgage endowment policies }}$

Not carrying out customer orders on a timely basis

Failure in compliance with money-laundering rules

Mis-selling of mortgage endowment policies

Failure in compliance with money-laundering rules

Failure in compliance with money-laundering rules

$\mathrm{S}$

S

$\mathrm{T}$

S

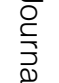

인

T!

할

ำ.

$\stackrel{0 .}{\circ}$

胥

SE

FSA

Mis-selling of mortgage endowment policies

Badly administering savings schemes; inappropriate handling of funds that put 30,000 customers at risk of losing money 
TABLE A1 (continued)

\section{Description of the 40 Cases}

\begin{tabular}{l}
\multicolumn{1}{c}{$\begin{array}{c}\text { Subsidiary } \\
\text { Name }\end{array}$} \\
\hline AXA Sun Life \\
Capita Trust \\
Company Limited \\
\\
Morgan Grenfell \& \\
Co. Limited
\end{tabular}

$$
\text { Co. Limited }
$$

Total

Fine

500,000

300,000

90,000

190,000

$\begin{array}{ll}\text { Jan. 15, 2004 } & \text { HBOS } \\ \text { Dec. 14, 2005 } & \text { HSBC Bank Plc } \\ \text { Nov. 17, 2005 } & \text { UBS AG } \\ \text { Jan. 13, 2005 } & \text { Hemscott }\end{array}$

Nov. 22, 2006

Berkshire Hathaway

\begin{tabular}{|c|c|c|}
\hline Nature of Misconduct & $\begin{array}{l}\text { Second } \\
\text { Party } \\
\text { (S) or } \\
\text { Third } \\
\text { Party } \\
\text { (T) } \\
\end{array}$ & $\begin{array}{l}\text { FSA } \\
\text { or } \\
\text { LSE }\end{array}$ \\
\hline Misleading advertisements & $\mathrm{s}$ & FSA \\
\hline Mis-selling of precipice bonds & $\mathrm{s}$ & FSA \\
\hline Delay in revealing relevant information to the market & $S$ & FSA \\
\hline $\begin{array}{l}\text { Failure to act in its customer's best interests and failure to } \\
\text { manage its conflicts of interests. Morgan Grenfell } \\
\text { commenced proprietary trading in seven of the } \\
\text { constituent securities of a client's program trade, prior to } \\
\text { its award, based on limited information provided to } \\
\text { enable the firm to quote for that business. The } \\
\text { proprietary trading resulted in the client paying more for } \\
\text { the program trade than it would otherwise have done. }\end{array}$ & $S$ & FSA \\
\hline $\begin{array}{l}\text { Failure to monitor adequately a sales strategy that } \\
\text { advocated the sale of non-pension products and failure } \\
\text { to ensure the suitability of sales }\end{array}$ & S & FSA \\
\hline Failure in compliance with money-laundering rules & T & FSA \\
\hline Transaction-reporting failures & $\mathrm{T}$ & FSA \\
\hline Transaction-reporting failures & T & FSA \\
\hline Misleading financial promotions & $S$ & FSA \\
\hline $\begin{array}{l}\text { Arranging two improper reinsurance transactions that } \\
\text { enabled an unnamed client to gain tax benefits by } \\
\text { transferring money among countries. In so doing, GenRe } \\
\text { U.K. breached FSA Principle } 2 \text { by not conducting its } \\
\text { business with due skill, care, and diligence. }\end{array}$ & $\mathrm{T}$ & FSA \\
\hline
\end{tabular}

(continued on next page) 
TABLE A1 (continued)

\section{Description of the 40 Cases}

\begin{tabular}{|c|c|c|c|c|c|c|c|c|}
\hline$\#$ & Date & $\begin{array}{l}\text { Listed Holding } \\
\text { Company Name } \\
\end{array}$ & $\begin{array}{l}\text { Subsidiary } \\
\text { Name }\end{array}$ & Fine & $\begin{array}{c}\text { Total } \\
\text { Compensation } \\
\end{array}$ & Nature of Misconduct & $\begin{array}{l}\text { Third } \\
\text { Party } \\
(\mathrm{T})\end{array}$ & $\begin{array}{l}\text { FSA } \\
\text { or } \\
\text { LSE }\end{array}$ \\
\hline 21 & Aug. 7, 2006 & $\begin{array}{l}\text { Merrill Lynch } \\
\text { International }\end{array}$ & & 150,000 & 0 & Transaction-reporting failures & $\mathrm{T}$ & FSA \\
\hline 22 & Apr. 11, 2006 & Deutsche Bank AG & & $6,363,643$ & 0 & $\begin{array}{l}\text { Market misconduct in running book-building transactions. } \\
\text { Deutsche Bank traded on Scania shares during the book } \\
\text { building. The trading was not transparent to the market } \\
\text { and was of a size and manner that contributed material } \\
\text { changes to Scania's share price. It also prevented } \\
\text { potential investors from gaining a full understanding of } \\
\text { the nature of supply and demand for Scania's shares. }\end{array}$ & T & FSA \\
\hline 23 & Mar. 16, 2006 & Capita Group & $\begin{array}{l}\text { Capita Financial } \\
\text { Administrators } \\
\text { Limited }\end{array}$ & 300,000 & 0 & Poor anti-fraud controls over client identities and accounts & S & FSA \\
\hline 24 & Nov. 16, 2007 & $\begin{array}{l}\text { Toronto Dominion } \\
\text { Bank }\end{array}$ & & 490,000 & 0 & $\begin{array}{l}\text { System and control failures in relation to one of its trading } \\
\text { books }\end{array}$ & S & FSA \\
\hline 25 & June 12, 2008 & $\begin{array}{l}\text { Woolworths Group } \\
\text { Plc }\end{array}$ & & 350,000 & 0 & $\begin{array}{l}\text { Failure to disclose information to the market in a timely } \\
\text { manner }\end{array}$ & S & FSA \\
\hline 26 & May 15, 2008 & AXA & Thinc Group Limited & 900,000 & 0 & $\begin{array}{l}\text { Not having adequate risk management and compliance } \\
\text { systems for its subprime mortgage business and failure } \\
\text { to take reasonable care to ensure that it had records to } \\
\text { prove that advice it gave to customers in relation to the } \\
\text { sale of subprime mortgages was suitable }\end{array}$ & S & FSA \\
\hline 27 & May 12, 2008 & Land of Leather & & 210,000 & 0 & $\begin{array}{l}\text { Ineffective monitoring or training in place to ensure that } \\
\text { the insurance was being sold fairly }\end{array}$ & $\mathrm{s}$ & FSA \\
\hline 28 & Jan. 16, 2008 & HSBC Group & HFC Bank & $1,085,000$ & 0 & $\begin{array}{l}\text { Failure to take reasonable care to ensure that the advice it } \\
\text { gave customers to buy Payment Protection Insurance } \\
\text { (PPI) was suitable and failure to have adequate systems } \\
\text { and controls for the sale of PPI }\end{array}$ & $\mathrm{s}$ & FSA \\
\hline 29 & Nov. 5, 2009 & UBS AG & & $8,000,000$ & $42,000,000$ & $\begin{array}{l}\text { System and control failures that enabled four employees } \\
\text { to carry out unauthorized transactions involving } \\
\text { customer money }\end{array}$ & $\mathrm{s}$ & FSA \\
\hline
\end{tabular}


TABLE A1 (continued)

\section{Description of the 40 Cases}

\begin{tabular}{|c|c|c|c|c|c|c|c|c|}
\hline \# & Date & $\begin{array}{l}\text { Listed Holding } \\
\text { Company Name }\end{array}$ & $\begin{array}{l}\text { Subsidiary } \\
\text { Name }\end{array}$ & Fine & $\begin{array}{c}\text { Total } \\
\text { Compensation }\end{array}$ & Nature of Misconduct & $\begin{array}{l}\text { Second } \\
\text { Party } \\
\text { (S) or } \\
\text { Third } \\
\text { Party } \\
\text { (T) }\end{array}$ & $\begin{array}{l}\text { FSA } \\
\text { or } \\
\text { LSE }\end{array}$ \\
\hline 30 & Sept. 8, 2009 & Barclays & $\begin{array}{l}\text { Barclays Capital } \\
\text { Securities Ltd. and } \\
\text { Barclays Bank Plc }\end{array}$ & $2,450,000$ & 0 & Transaction-reporting failures & $\mathrm{T}$ & FSA \\
\hline 31 & Jan. 20, 2009 & $\begin{array}{l}\text { Wolfson } \\
\text { Microelectronics } \\
\text { Plc }\end{array}$ & & 140,000 & 0 & Delay in revealing relevant information to the market & $\mathrm{s}$ & FSA \\
\hline 32 & Nov. 24, 2009 & $\begin{array}{l}\text { Nomura International } \\
\text { Plc }\end{array}$ & & $1,750,000$ & 0 & $\begin{array}{l}\text { Widespread system and control failures around book } \\
\text { marking }\end{array}$ & $\mathrm{T}$ & FSA \\
\hline 33 & Apr. 8,2010 & Credit Suisse & & $1,750,000$ & 0 & Transaction-reporting failures & $\mathrm{T}$ & FSA \\
\hline 34 & Apr. 8, 2010 & Nomura Holdings & $\begin{array}{l}\text { Instinet Europe } \\
\text { Limited }\end{array}$ & $1,050,000$ & 0 & Transaction-reporting failures & $\mathrm{T}$ & FSA \\
\hline 35 & June 7, 2010 & $\begin{array}{l}\text { Close Brothers } \\
\text { Group }\end{array}$ & $\begin{array}{l}\text { Close Investments } \\
\text { Limited }\end{array}$ & 98,000 & 0 & Failure to properly protect and segregate client money & S & FSA \\
\hline 36 & Aug. 25, 2010 & Societe Generale & & $1,575,000$ & 0 & Transaction-reporting failures & $\mathrm{T}$ & FSA \\
\hline 37 & June 3, 2010 & $\begin{array}{l}\text { J.P. Morgan } \\
\text { Securities }\end{array}$ & & $33,320,000$ & 0 & $\begin{array}{l}\text { Failure to protect client money by segregating it } \\
\text { appropriately }\end{array}$ & $S$ & FSA \\
\hline 38 & Nov. 23, 2009 & $\begin{array}{l}\text { Environmental } \\
\text { Recycling } \\
\text { Technologies }\end{array}$ & & 0 & 0 & Delay in revealing relevant information to the market & $\mathrm{s}$ & LSE \\
\hline 39 & June 19, 2008 & $\begin{array}{l}\text { Meridian Petroleum } \\
\text { Plc }\end{array}$ & & 75,000 & 0 & Delay in revealing relevant information to the market & $S$ & LSE \\
\hline 40 & Feb. 1, 2008 & $\begin{array}{l}\text { Subsea Resources } \\
\text { Plc }\end{array}$ & & 0 & 0 & Delay in revealing relevant information to the market & $\mathrm{s}$ & LSE \\
\hline
\end{tabular}




\section{References}

Alexander, C. R. "On the Nature of the Reputational Penalty for Corporate Crime: Evidence.” Journal of Law and Economics, 42 (1999), 489-526.

Armour, J.; B. S. Black; B. R. Cheffins; and R. Nolan. "Private Enforcement of Corporate Law: An Empirical Comparison of the United Kingdom and the United States." Journal of Empirical Legal Studies, 6 (2009), 701-745.

Bhagat, S., and R. Romano. "Event Studies and the Law Part I: Technique and Corporate Litigation." American Law and Economics Review, 4 (2002), 141-168.

Blair, M.; G. Walker; and R. Purves. Financial Services Law, 2nd ed. Oxford, UK: Oxford University Press (2009).

Davies, P. Davies Review of Issuer Liability: Final Report. London, UK: HM Treasury (2007).

Fama, E. F.; L. Fisher; M. C. Jensen; and R. Roll. "The Adjustment of Stock Prices to New Information." International Economic Review, 10 (1969), 1-21.

Financial Services Authority. Decision Procedures and Penalties Manual (DEPP). London, UK: FSA (2010).

Haslem, B.; I. Hutton; and A. Smith. "How Much Do Corporate Defendants Really Lose? A New Verdict on the Reputation Loss Induced by Corporate Litigation." Financial Management, 46 (2017), 323-358.

Jarrell, G., and S. Peltzman. "The Impact of Product Recalls on the Wealth of Sellers." Journal of Political Economy, 93 (1985), 512-536.

Karpoff, J. M. "Does Reputation Work to Discipline Corporate Misconduct?" In Oxford Handbook of Corporate Reputation, M. Barnett and T. G. Pollack, eds. Oxford, UK: Oxford University Press (2012).

Karpoff, J. M.; A. Koester; D. S. Lee; and G. S. Martin. "Database Challenges in Financial Misconduct Research.” Working Paper, Georgetown University (2014).

Karpoff, J. M.; D. S. Lee; and G. S. Martin. "The Cost to Firms of Cooking the Books." Journal of Financial and Quantitative Analysis, 43 (2008), 581-611.

Karpoff, J. M., and J. R. Lott Jr. "The Reputational Penalty Firms Bear from Committing Criminal Fraud." Journal of Law and Economics, 36 (1993), 757-802.

Karpoff, J. M., and J. R. Lott Jr. "On the Determinants and Importance of Punitive Damage Awards." Journal of Law and Economics, 42 (1999), 527-573.

Karpoff, J. M.; J. R. Lott Jr.; and E. W. Wehrly. "The Reputational Penalties for Environmental Violations: Empirical Evidence." Journal of Law and Economics, 48 (2005), 653-675.

Klein, B., and K. B. Laffler. "The Role of Market Forces in Assuring Contractual Performance." Journal of Political Economy, 89 (1981), 615-641.

Kothari, S. P., and J. B. Warner. "Econometrics of Event Studies." In Handbook of Corporate Finance: Empirical Corporate Finance, Vol. 1, B. E. Eckbo, ed. Amsterdam, Netherlands: Elsevier (2007).

London Stock Exchange. Inside AIM. London, UK: LSE (2009).

London Stock Exchange. AIM Rules for Companies-February 2010. London, UK: LSE (2010).

Mitchell, M. L., and M. T. Maloney. "Crisis in the Cockpit? The Role of Market Forces in Promoting Air Travel Safety." Journal of Law and Economics, 32 (1989), 329-355.

Murphy, D. L.; R. E. Shrieves; and S. L. Tibbs. "Understanding the Penalties Associated with Corporate Misconduct: An Empirical Examination of Earnings and Risk." Journal of Financial and Quantitative Analysis, 44 (2009), 55-83.

Shapiro, C. "Premiums for High-Quality Products as Returns to Reputations." Quarterly Journal of Economics, 98 (1983), 659-680. 